\title{
TOWARDS A VYGOTSKYAN MODEL OF WRITING ASSESSMENT
}

\author{
LPD Faragher \\ CA Puhl \\ JJ Swartz
}

This article challenges a widely current model of second language writing assessment which focuses on language errors. A significant sample of the examination writing of matriculants from the then (1991) Department of Education and Training in the Cape Town area is assessed using elements of a Vygotskyan approach. Rather than focusing on surface errors, the analysis explores some of the conceptual and communicative processes involved, using three tools: word count, analysis of metaphors, and exploration of idiosyncratic expressions. This preliminary investigation describes underlying aspects of language proficiency in the group studied, and suggests areas to be clarified in developing a new approach to proficiency assessment.

In hierdie artikel word 'n model om geskrewe tweede taal te evalueer wat tans wyd in gebruik is, aangespreek. 'n Beduidende monster van die geskrewe eksamens van die 1991-matrikulante van die voormalige Departement van Onderwys en Opleiding in die Kaapstadgebied is volgens elemente van die Vygotskyaanse benadering geëvalueer. Die fokus is nie op oppervlaktefoute nie, maar op sommige van die konseptuele en kommunikatiewe prosesse wat betrokke is. Drie instrumente word gebruik, nl. woordtelling, analise van metafore en die eksplorasie van idiosinkratiese uitdrukkings. Hierdie voorlopige ondersoek beskryf die onderliggende aspekte van die studiegroep se taalvaardighede en maar voorstelle oor areas wat uitgeklaar sal moet word in die ontwikkeling van ' $n$ nuwe benadering tot vaardigheidsevaluasie.

\section{INTRODUCTION}

The prevailing view of language up to and including most of the 1960's, according to Savignon, (1983, also Brown, 1994), was of language as basically a collection of grammatical structures. Writing assessment was largely a matter of isolating the structures to see if the learner could apply grammatical rules and get the words, phrases and sentences "right". Test scores in practice were heavily dependent on grammatical correctness; there was a preoccupation with grammatical error.

The period after World War II saw energetic development of second language assessment (Savignon, 1983). Discrete-point testing characterised this period, in which separate structures 
were examined in the context of the sentence. Even when the context of a larger written text was provided, the task as well as the scoring still focussed on discrete structural features, on form rather than on meaning. Test takers typically faced multiple choice questions and had to find or produce one "correct" answer.

In contrast, the 1970's saw the rise of integrated testing, in which several features of the language combine with the focus on meaning (Savignon, 1983). This view seems to have grown in general acceptance into the 1990 's. It is based on a conception of language which takes into account the social nature of people in interaction, whether interacting face to face or interacting through written text. In fairly typical assessment, test takers are asked to produce a piece of written discourse, an integrative task, which is then scored integratively, with focus on total communicative effect. While it is possible to score an integrative task in a discrete way, which involves looking for and counting discrete linguistic features, as in the recent past, this is hardly desirable. To score such a task globally, a trained rater assigns an overall rating based on a combination of features, such as appropriateness, coherence, and effectiveness.

Writing assessment practices have evolved through marking grids or profiles to rating scales (Lowe 1988). Marking grids typically assign points along several dimensions such as content, organisation, vocabulary, and language use, along with subsets of each one of these dimensions. The points are added up to obtain a mark (e.g., Marking Profile for NSC English Second Language Higher Grade, cited in Faragher, 1995).

Rating scales are currently in use in world-respected tests of proficiency in English as a Second Language (ESL). Some of these tests include writing: for example the Test of English as a Foreign Language, or TOEFL, and the examination of the International English Language Testing System, or IELTS. The TOEFL is given in 180 countries, with over 800,000 people registered to take it in 1993-94 (TOEFL 1995-96). Its optional Test of Written English (TWE) requires an essay, which is scored according to a global rating scale of 1-6. The IELTS, given in 100 countries, requires two writing tasks as an integral part of the examination rather than an option. Each task is scored according to a global scale of 1-8. Both tests define the various numbers in their ratings by detailed verbal descriptions. Raters who are trained in the system then determine the level which best describes a piece of writing. In the end, what must be assessed is the total integrated effect of the communicative act (Savignon 1983), including not just grammatical competence but also larger competencies such as discourse competence, sociolinguistic competence, and strategic competence (Canale and Swain, 1980; Swain 1990 in Brown 1994).

But evolution is uneven and the development of language testing as a field in itself does not imply that everyone who conducts ESL assessment also thinks as many language testing experts now do. Even the TOEFL cited above still uses discrete-point testing to assess writing in its basic test battery, with the focus on recognition of appropriate standard written English in a multiple choice format. In the experience of all three authors, many people in a variety of assessment roles, such as classroom teachers, matriculation examination markers, training 
programme officials, and tertiary admissions personnel, who are not necessarily trained in up-todate practices in writing assessment, tend to depend too heavily on error as an index of writing competence. It is not difficult to propose reasons for this perspective, in that errors are obvious and quantifiable. However, it is questionable whether such assessment has sufficient validity, given the range of factors involved in the productive use of a second or additional language.

This perspective, applying to a broader group than teachers, is caught in the words of Cazden (in Savignon 1983: 231):

Normally, in out-of-school conversations, our focal attention as speakers and listeners is on the meaning, the intention, of what someone is trying to say. Language forms are themselves transparent; we hear through them to the meaning intended. But teachers, over the decades if not centuries, have somehow gotten into the habit of hearing with different ears once they go through the classroom doors. Language forms assume an opaque quality. We cannot hear through them; we hear only the errors to be corrected.

Results of such assessment may unwittingly mask some of the broader language competencies that the learner brings to the writing process. The issue becomes crucial when the assessment of ESL writing is done for awarding of credentials or for selection purposes (Henning 1987), including when exiting from a programme of study or training, as in the matriculation exam, or when applying for entrance to further training or development opportunities, as in tertiary education or industrial training. If the assessment process itself overemphasises surface features of language use, such as grammatical correctness, it may conceal the very language proficiency it is intended to reveal. It may also fail to disclose an individual's potential for further development.

The problem becomes particularly acute when consideration is given to the situation of a great many South African students, mainly black, for whom English is often a third or fourth language, and who have had relatively poor schooling in schools that were developed along racially discriminatory lines. It is important especially for these disadvantaged students that assessment of writing go beneath the errors to see if the writers are actually able to accomplish meaningful communicative goals. A further problem noted anecdotally by Faragher (1995, personal communication) as well as by others, involves the fact that negative judgements based on observed language errors are often made, quite unfairly, of these learners' intellectual competence. It becomes all the more important to find a way to assess language competence beyond error.

This article reports on provisional research towards an alternative approach to assessing second language writing in English. Instead of focusing on language errors, assessors attempt to identify cognitive strategies the learner uses to accomplish the written task, thereby acknowledging process over product. The assumption is that if such strategies reflect awareness of the communication task and appropriate attempts to accomplish it, this may evidence a level of language competence that traditional assessment overlooks. Indeed, the very existence of surface 
errors, in some cases becoming 'inter language' (Brown 1994), may indicate the use of a particular cognitive strategy in the learner's attempt to communicate. This positive approach to language assessment may produce a different, more accurate picture of especially L2 competence and potential.

Cognitive strategies were of particular interest to Vygotsky, who took the interrelation of thought and language as the focal issue of human psychology (Vygotsky 1978, 1986; Carroll, 1963). His views support a focus on learners' competencies rather than on their lacks. His work has inspired recent interest and research efforts. Lantolf and Frawley (1985) provide an extended criticism of traditional second language assessment approaches from a Vygotskyan perspective; Lantolf and Appel (1994) offer a Vygotskyan paradigm for L2 research, reporting on various studies rooted in his theory. A Vygotskyan approach, with perhaps greater awareness of process as well as the influence of context, may prove to be more useful than many assessment approaches currently employed.

\section{A VYGOTSKYAN PERSPECTIVE}

One of the key concepts within a Vygotskyan perspective is regulation (Vygotsky 1978). In his quest to explore the development and function of the human mind, Vygotsky focusses on consciousness, which he feels links the individual's knowledge to his or her behaviour (Lantolf and Appel 1994). He sees human consciousness as composed of 'the self-regulatory mechanisms that humans deploy in solving problems' (Lantolf and Appel 1994: 3). In Vygotskyan theory, when we become competent in a second language (and perhaps as we learn anything new), we follow the same developmental sequence involving regulation as when we were children, learning to cope with realities through ever more symbolic means. This sequence has three stages which can be observed in the person's strategic use of language: object-regulation, in which a person is controlled by the environment, when the person's attention is 'fixed on an object . . . and it dominates cognition at that moment' (Foley 1991: 63); other-regulation, in which a person is controlled by another person; and self-regulation, in which language is used to control oneself and others, often by self-directed utterances which indicate mature linguistic ability (Foley 1991: 63). This last represents the ability to express oneself clearly and cogently. Self-regulation, the highest stage, is 'independent strategic functioning' (Lantolf \& Frawley 1985); the person manages the whole situation, others, and self, by means of language.

Each stage is manifested by its style of discourse, and each style of discourse is marked by certain kinds of strategies. It is possible to know the stage by examining the discourse and identifying the strategies used. Useful tools of discourse analysis are later proposed, which are specific to stages shown by second-language (L2) learners of English.

These stages are dynamic and may vary relative to a particular task. When a learner faces a task experienced as difficult, he/she can drop back to object- and other- regulation to work up to self- 
regulation regarding this task. This is the Vygotskyan principle of continuous access (Frawley and Lantolf 1984).

With self-regulation comes control of one's world. Thus transitional structures, which are described as idiosyncratic forms, reveal the learners' efforts to achieve self-regulation. L2 interlanguage shows the learner's strategy for knowing the discourse rather than relating it, and the peculiarities of L2 discourse are seen as strategies in other- and object-regulation, used by the producers to achieve self-regulation. Therefore the odd forms are functional for the knower/producer who is attempting to learn/acquire/use another language. Frawley and Lantolf (1984) maintain that the forms produced in the task are all indicative of the learners' 'cognitive states' in the task and all the forms are relevant to their attempts to complete the task. This conforms to the view that linguistic forms used are meaningful to the user and are part of the attempt to communicate and therefore to achieve self-regulation.

\section{L2 PROFICIENCY AND VYGOTSKYAN THEORY}

When ideas are spoken or written down (externalised), they provide evidence of the cognitive process learners have used to achieve self-regulation.

This is how the learner also demonstrates the development of consciousness and self-reflection, which are forms of higher mental activity facilitated through the development of language and concepts. Vygotsky saw human consciousness as activity engaged in reconstructing the environment and representing that reconstruction of the environment. This activity is an effort to reflect, in activity, what is going on in the mind. Thus, reflection is an active effort to manifest the mind's organisational power and it is manifested in the spoken or written word (Wertsch 1985). In the Vygotskyan perspective, proficiency is evidenced in output that provides evidence of self-regulation, consciousness and reflection. It is telling the reader something about the mind of the writer.

When an evaluator looks at how a learner uses language in an L2 for a specific task from a Vygotskyan perspective, the evaluator asks: At which stage of regulation is the learner functioning? If at the object-regulation stage, there is quite a way to go before the learner can regulate self. If at the other-regulation stage, the learner is part-way toward mastery. If at the self-regulation stage, the learner is using the language effectively. This implies that proficiency is really self-regulation. There may be errors in terms of grammatical rules or norms of usage, but these errors neither nullify the strategies being used nor destroy learner effectiveness. This is not to say that errors are acceptable; it is to say that the learner is capable (i.e. can get things done, can handle others, and can apply self in the L2), though not yet perfect.

Thus a deficit model of language assessment, based mainly on surface features, and often involving judgement of cognitive abilities based on imperfections in those surface features, is rejected as invalid and even harmful. In Vygotskyan thinking the learner is judged in terms of 
his/her own level of functioning, and not only in terms of mother-tongue "norms", which are to some degree arbitrary. This is especially crucial in South Africa because various Englishes seem to be becoming accepted in their own right, rather than as unfortunate deviants from some "pure" standard. The use of a variety of English, therefore, should not be seen to indicate a cognitive deficit on the part of the user. It becomes even more important to find a way to look beneath surface manifestations to identify the cognitive functioning behind the language.

\section{VYGOTSKYAN WRITING ASSESSMENT: A STUDY}

It was hypothesized that Department of Education and Training (DET) matriculants who pass English would show self-regulation strategies in their examination essays, despite the presence of 'errors', because writing, in Vygotskyan thought (Kozulin 1990), is a model for the reconstruction of individual consciousness. One third of all 1991 successful DET matriculant essays in the Cape Town area were selected randomly, totalling 116 papers; these were analyzed to determine whether the writers were self-regulating (Faragher 1995). These learners were studied as a group because of the limited input of only one writing sample available per learner. They had already achieved a measure of competence by traditional standards, such as reaching Standard 10 and being allowed to write the exam, and the language produced (under limits of time and choice) was taken to be available to learners in general in this sample. Though this 'pooling' of data may seem arbitrary, it can be supported by the Vygotskyan $(1978,1986)$ notion of the social or shared nature of language.

The essay writers could choose one of six topics, which were: a discussion of the use of English as a medium of learning when it is not one's mother tongue; improving the lot of women in South Africa; a study about betrayal of trust; a description of one's residential area; an unfair incident; and a mining accident which affected safety regulations.

Three analytical tools based on Vygotskyan theory explicated below, and suitable for use with written data, were developed: a word count, an analysis of metaphors used, and an analysis of idiosyncratic expressions. These tools jointly inform the reader about what the writers bring to the task, how they relate to it, and how they accomplish it; in other words, each tool indicates the stage of proficiency, defined above as one of the three developmental stages in regulation.

\section{The Word Count}

Vygotsky (1986) sees words as fundamental units of language, stored in the individual's subconscious and produced and combined as a concept is developed and realised in articulation. A word stands for a rich cluster of interlocking ideas. Vygotsky (1986: 256) argues: 'Consciousness is reflected in a word as the sun in a drop of water. A word relates to consciousness as a living cell relates to a whole organism'. He sees words as tools, and, in order to see to what extent these tools are controlled by the essay writers, a word count was taken as a guide to the extent of the learners' 'concept bank' and of their lexical competence as a group. 
A word list was generated from the essays using only base forms of content words. It was then compared with a scientifically constructed data base, West's Minimum Adequate Vocabulary (MAV), which represents vocabulary required for social interaction. The data contained 1331 more words than the MAV, suggesting that the writers of the essays have richer vocabularies than needed. Word count results thus support the hypothesis that these L2 writers were a selfregulating group.

\section{Metaphors}

Metaphors are comparisons which make it possible to think and speak about abstract concepts by linking them to a sensory base.

Several authors (Di Pietro, Kaput, \& Nietsche, in Kessler \& Quinn 1987: 179) describe language as a 'universe of knowledge' and believe that 'the nature of human thinking is essentially metaphoric and the metaphorising process is the primary means for creating and, especially, transferring meaning from one universe of knowledge to another'. Metaphor makes abstract thought possible by transcending the concrete, sensory 'universe of knowledge'. This suggests that the process of thinking in terms of metaphor can assist L2 writers to transfer themselves from their L1 to their L2 - 'from one universe of knowledge to another'.

Metaphors generated in this study, such as people who stay in zink houses are as hard as zink, are regarded as indicators of complex intellectual activity which is synthesised in inner speech. Metaphors show self-regulation in that abstract concepts are present and are being communicated in possibly non-conventional ways (yet nevertheless being communicated), so that the reader receives a clear idea of the writer's intention.

Further examples of metaphors are taken from essays on the most popular essay topic, viz. "Discuss the advantages and disadvantages of using English as a medium of learning when it is not your mother tongue. Refer mainly to your experience in the classroom and also to wider considerations such as further education, employment and the development of African languages as such."

In this essay, a large number of metaphors was used to depict English as a destructive force. The metaphors used by students to depict the destruction of their own language were vivid and varied: African languages are dying/have no future; they spoke of breaking the language, killing the nation and attacking our cultures. The link between language and culture is so closely made that the concepts sometimes seem to be used interchangeably. English is seen as an intruding language in your peaceful Xhosa speaking world. English is destructive and dominating: their mother languages were stolen from them during slavery; English conquers the African languages; it causes you to forget your mother, it spoil(s) the minds of African people and changes their minds; it is subversive and has the power to overcome other languages ... it is the language of the imperialists and has stolen our love for our African languages; they 
dump their languages just like rubbish and it degrades our culture. We infiltrated English language and lost our mother tongue languages. They wrote of how their workmates will undermine your language especially if it is an African language.

The use of words like breaking, killing, intruding, stolen, conquers, spoils, overcome, dump, degrades, infiltration and undermine, all evoke images of the power of English to destroy what is precious. There is also a strong sense of being victims of forces beyond their individual control.

Learning English is often linked to adopting the ways of 'western civilisation' and means that we cannot stick to our roots. English is seen as a disruptive force; as an agent of unwished-for change, it is even seen as a criminal element. The necessity to be able to communicate in English came as a blow to our African languages and we are seeing it as something which wants to still are (steal our) customs and culture. Beware of it. English has caused people to neglect their home languages - African languages are detoriating (deteriorating) because they are not cared for. The sense of failure to nurture their home languages is expressed often: people become careless about their mother tongue and care more about the foreign language. They feel guilty and angry about the power of English.

These examples of metaphor indicate that the writers are engaging in communication.

The generation of successful metaphors indicates the ability to think analogically (Di Pietro 1976). It involves the construction of mental models and comparisons that interact and cause reformulation of the communication by the receiver. In this way the reader is invited into, and involved in, the world of the writer. Analysis of metaphors used in the study indicates that these writers caused rich and full communication to take place through the generation of fresh metaphors. In this sense, they can be said to be at the self-regulating stage.

\section{Idiosyncratic Forms}

Idiosyncratic forms constitute the third analytical tool used to test the DET essays for evidence of self-regulation. As Vygotsky (1978) used them in his study of the development of higher mental processes, idiosyncratic forms are words or utterances produced by a child to help him or her accomplish some goal, to act on the world, to regulate. The child creates the language he or she needs as tools. Similarly, individual writers of the essays, ESL learners, may also use nonstandard expressions specific to themselves. They may also use non-standard English expressions specific to their speech communities, which in the present study have been taken as idiosyncratic in a wider sense. These are defined here as expressions fossilised into what is termed a Xhosa-English Version (XEV), or in Williams' (1989) words, a 'non-native institutionalised variety of English (NIVE)'. They are typical forms of usage and interaction which are part of the XEV as used in people's daily lives. Though the acceptance of varieties of English remains controversial, idiosyncratic forms as used in this study constitute a strategy for making meaning and should not be seen as 'errors'. An expression like to voice out the dislikes about my area is an example. 
Other typical forms are the tactics adopted for adding emphasis:

it is not that much important

it is useful such that $=$ it is useful that ...

we can be very much pleased

some few questions

There are some lexical idiosyncracies - the word bored is often used to indicate irritation or frustration:

if we're bored about the fight, i.e. fed up with fighting

it was where they became bored they had persuaded my supervisor that I was a thief and she did not listen to them.

Regret has become a verb that means rejected

Ifeel so regreted. It is also common for applications to be regretted.

to regreat (regret) your mother tongue.

Provision is the food and drink a person takes on a journey.

my parents made a provision for me.

A car can also be defined as a transport;

there wasn't even a single transport.

The use of wear to mean dress is common currency:

wearing as angels, meaning to be dressed as angels.

Also commonly used is: I get up in the morning and I wear my clothes.

diosyncratic forms such as those quoted here are used by the students to act on others, in this ase, the markers of the examination. Their meaning seems clear and direct. Rather than being serceived as error-ridden, the language used can be seen to indicate that the users are not objectegulated or other-regulated but self-regulated.

\section{ZONCLUSION}

t can be argued that the writers wrestle with their ideas and their vocabulary to produce netaphors and idiosyncratic expressions. In Vygotskyan terms, they use the words, metaphors and idiosyncratic expressions as objects and others to bring them to the self-regulation of the completed, meaningful essays. The extent of the word count and success of the metaphors and 
idiosyncratic expressions suggest greater intellectual competence than might be suggested by some so-called non-standard forms ('errors') evident on the surface of the texts. The writers understand their communication task and make successful if imperfect attempts to accomplish it. Indeed the writers can be described in Vygotskyan terms as self-regulating.

This research represents a preliminary exploration of the possibility of assessing student writing in a way which attempts to take into account the cognitive strategies students use rather than evaluating second-language competence in terms of native-speaker norms. The study suggests that this kind of assessment would be useful to pursue.

Because the essays studied here were already those of rather successful students, only the highest stage of regulation was explored. Further work could determine ways to distinguish objectregulation and other-regulation as shown in student test essays or other writing samples.

The view of language in the Vygotskyan paradigm is far from that of language as a collection of grammatical structures, a view which prevailed perhaps for centuries (Savignon 1983) and which persists among many people in roles which require assessment of ESL writing. The most significant implication requires a shift away from preoccupation with errors in surface features of language while ignoring the deliberate metacognitive strategies operating in the use of the language as regulating tool. In this light, the idea of discrete-point tests of language competence seems rather incongruous. Evidence from student essays illustrates command of the three tools of words, metaphor, and idiosyncratic forms, if not all of the surface features of language as yet.

The Vygotskyan view differs, though not so drastically, from language as social interaction, upon which integrative, communicative testing is based. Both are concerned with what one does with language, rather than what one knows about it. They share an emphasis on the influence of, and the need to influence, other people, whether live (oral) or through a text (written). But while the one approach examines the product of interaction, as in the use of rating scales, the other examines the process of it, as underlying strategies.

The approach is still far from addressing practical concerns of assessment for large numbers of anonymous L2 users. However, it at least suggests a new way of viewing error. Also, by exploring a way to examine what the learner can do regarding L 2 use by determining the stage of mature cognitive functioning relative to a specific, representative task, we hope to contribute toward development of a model for more equitable assessment of L2 competence and metacognitive functioning.

\section{REFERENCES}

BROWN, HD. 1994. Principles of language learning and teaching. Englewood Cliffs, New Jersey: Prentice-Hall. 
CANALE, M AND M SWAIN. 1980. Theoretical bases of communicative approaches to second language teaching and testing. Applied Linguistics, 1: 1-47.

CARROLL, JB. 1963. Book review: Thought and Language (1962 edition). Harvard Educational Review, 33(2): 246-251.

DI PIETRO, RJ. 1976. Language as human creation. Washington, D.C.: Georgetown University Press.

FARAGHER, LDP. 1995. Reading for riches: A Vygotskyan analysis of English writing by DET matriculants. Unpublished M.Ed. thesis. University of Stellenbosch, Stellenbosch.

FOLEY, J. 1991. A psycholinguistic framework for task-based approaches to language teaching. Applied Linguistics, 12(1): 62-75.

FRAWLEY, W AND JP LANTOLF. 1984. Speaking and self-order: a critique of orthodox L2 research. Studies in second language acquisition, 6: 143-159.

HENNING, G. 1987. A guide to language testing: Development, evaluation, research. New York: Newbury House.

INTERNATIONAL ENGLISH LANGUAGE TESTING SYSTEM (IELTS). 1995. Cambridge: University of Cambridge.

KESSLER, C AND ME QUINN. 1987. Language minority children's linguistic and cognitive creativity. Journal of Multilingual and Multicultural Development, 8 (1-2): 183188.

KOZULIN, A. 1990. Vygotsky's psychology. Cambridge, Massachusetts: Harvard University Press.

LANTOLF, JP AND C APPEL (Eds). 1994. Vygotskian approaches to second language research. Norwood, New Jersey: Ablex.

LANTOLF, JP AND W FRAWLEY. 1985. Oral proficiency testing: a critical analysis. The Modern Language Journal, 69 (IV).

LOWE, P. 1988. The unassimilated history. In Lowe, P and Stansfield, CW. Eds. 1988. Second language proficiency assessment: Current issues. Englewood Cliffs, New Jersey: Prentice-Hall, 11-51. 
SAVIGNON, S. 1983. Communicative competence: Theory and classroom practice. Reading, Massachusetts: Addison-Wesley.

TEST OF ENGLISH AS A FOREIGN LANGUAGE (TOEFL). 1995-96. Bulletin of Information. Princeton, New Jersey: Educational Testing Service.

VYGOTSKY, LS. 1978. Mind in society: The development of higher psychological processes. Cambridge, Massachusetts: Harvard University Press.

VYGOTSKY, LS. 1986. Thought and language. Cambridge, Massachusetts: MIT Press.

WEST, M. 1960. Teaching English in difficult circumstances. London: Longman.

WERTSCH, JV. 1985. Vygotsky and the social formation of mind. Cambridge: Harvard University Press.

WILLIAMS, J. 1989. Language acquisition, language contact and nativized varieties of English. RELC Journal, 20(1): 39-69. 